\title{
CHAPTER 26 \\ Defeating Energy Poverty: Invest in Scalable Solutions for the Poor
}

\author{
Daniel M. Kammen
}

Energy and persistence conquer all things.

-Benjamin Franklin

Summary Energy poverty is arguably the most pervasive and crippling threat society faces today. Lack of access impacts several billion people, with immediate health, educational, economic, and social damage. Furthermore, how this problem is addressed will result in the largest accelerant of global pollution or the largest opportunity to pivot away from fossil fuels onto the needed clean energy path. In a clear example of the power of systems thinking, energy poverty and climate change together present a dual crisis of energy injustice along gender, ethnic, and socioeconomic grounds, which has been exacerbated if not outright caused by a failure of the wealthy to see how tightly coupled our global collective fate is if addressing climate change fairly and inclusively does not become an immediate, actionable priority.

While debate exists on the optimal path or paths to wean our economy from fossil fuels, there is no question that technically we now have sufficient knowledge and a sufficient technological foundation to launch and to even complete decarbonization. What is critically needed is an equally powerful social narrative to accelerate the clean energy transition. Laudato Si' provides a compelling foundation built on the narrative around the health, climate, and social benefits of a global green energy transition. The Green New Deal in the USA is a political movement that grows from this new understanding of sound stewardship and respect for the planet and its inhabitants.

This chapter presents examples and formulation of an action agenda to defeat energy poverty and energy injustice.

D. M. Kammen $(\bowtie)$

Energy and Resources Group \& Goldman School of Public Policy,

University of California, Berkeley, Berkeley, CA, USA

e-mail:kammen@berkeley.edu 


\section{The Multifaceted Nature of Energy Poverty and Injustice}

In what has become one of the most important and widely quoted assessments of the current state of energy poverty, we now hear daily that "over one billion people today lack access to modern energy services."

This striking statement has become the rallying cry of the United Nations, the World Bank, and a myriad of nongovernmental groups. What is less widely discussed is how central energy poverty is related to lack of food quality, high levels of indoor air pollution, and lack of quality water resources. Energy poverty is health poverty.

\section{A Framework for Learning and Innovation}

A variety of factors - all shameful in hindsight-have retarded the progress of a pro-poor, pro-environment agenda for research, testing, and action. The problems of household particulate pollution-black carbon-and trace gas pollution from indoor cooking and heating have been known and studied since the 1950s, and yet only recently has there been any significant scale-up of the solutions.

These are many examples of neglected yet critically needed science for these seemingly commonplace or mundane issues. Cookstoves, clean energy, climate change, and social, ethnic, and other injustices all fall squarely into this area and have arguably been under-researched. One useful theoretical framework in which to assess the impact of innovations is to distinguish between "fundamental science" and "use-inspired" or applications-motivated science. In his seminal book Pasteur's Quadrant, the political scientist Donald Stokes summarized this value in a classic $2 \times 2$ matrix of opportunities (Fig. 26.1).

It is clear that raising the mundane to an intellectual, political, and commercial level comparable to other texts and tenets of society is vitally needed for the natural, social, psychological, and policy tools required for energy access sustainability. If we utilize it effectively, Laudato $S i$ ' can be one of these grand ethical and intellectual levers.

Energy poverty exists at many scales: from the classic "three-stone fires" of rural homes in the poorest nations to rapidly growing urban communities, to rich nations that deny their own citizens even the most basic forms of energy infrastructure. In the next three sections, we illustrate the power of an approach that values the Pasteur's quadrant perspective for (a) rural cookstoves, (b) mini-grids for community energy services, and (c) the need and opportunity to transform the dirtiest largescale grids to meet both household and industrial energy needs. Sadly, while attention is often focused on the lack of energy for the poor, we recently found that even where rooftop solar power is expanding rapidly, such as in parts of the USA, access is often socially uneven and unjust. In a survey across the USA, we recently found $40-70 \%$ lower rates of photovoltaics (PV) in deployment in Latino and African American neighborhoods than the average, and 20-30\% higher rates of deployment in white majority areas (Sunter, Castellanos, \& Kammen, 2019). 


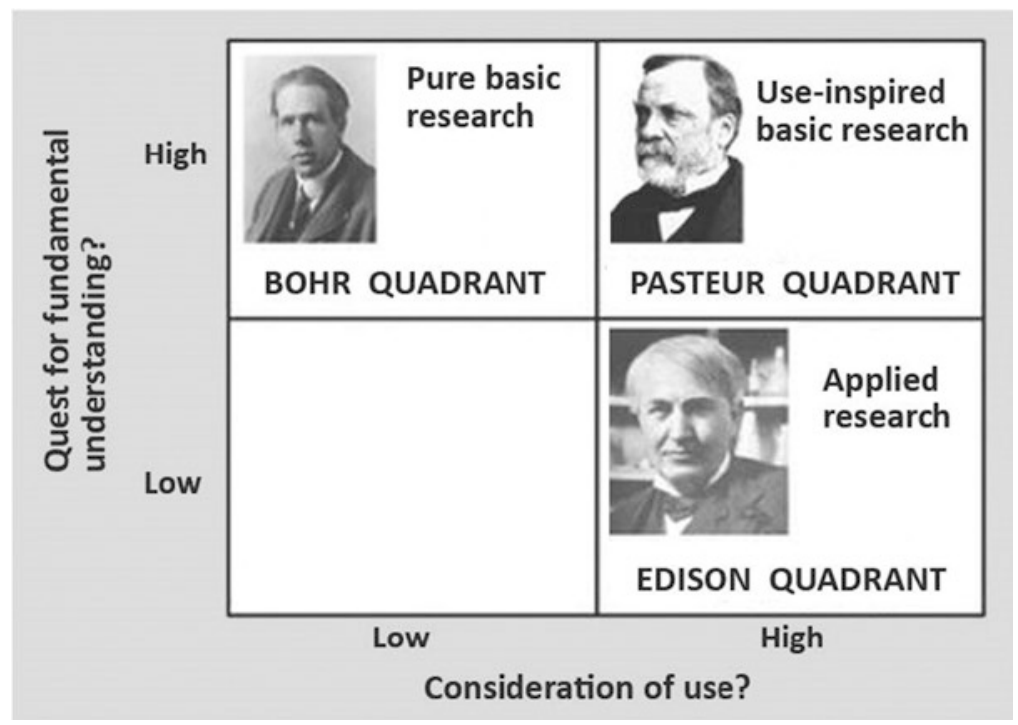

Fig. 26.1 Pasteur's quadrant and the power of formulating formerly applied research as fundamental (Stokes, 1997). The empty "Low-Low" quadrant has been variously and humorously described, generally with self-deprecation as the zone of "university presidents" or of "social media gadflies"

\section{The Intra-household Scale: Cookstoves, Women, and Health}

Women — who gather or purchase fuel, cook, and handle fire considerably more frequently than men-also have much higher exposure to the health impacts of energy use, including respiratory or eye diseases due to indoor smoke, burns, or back pain, and injuries from carrying heavy loads. While these increased health risks have long been recognized (Kammen \& Lankford, 1990; Kammen, 1995), detailed analysis illustrates that even the scientific tools used for quantifying exposure and disease relationships need to pay attention to details of women's work to properly assess the magnitude of the health risks associated with household energy tasks.

A rich literature exists on the exposure to indoor smoke under actual conditions of use and has shown that stove emissions are highly episodic and that peaks in emissions commonly occur when fuel is added or moved, the stove is lit, the cooking pot is placed on or removed from the fire, or food is stirred (Fig. 26.2; Ezzati \& Kammen, 2001, Bailis, Ezzati, \& Kammen, 2005). Quantitative and qualitative data on time-activity budgets also indicate that female household members are consistently closest to the fire when the pollution level is the highest. Other household members may be outside or away from the house at such times, especially during the hours when the fire is lit or extinguished.

In a long-term study of 500 villagers in central Kenya, we explored both indoor air pollution and health impacts on families using a range of stove and fuel combinations (Bailis et al., 2005; Ezzati \& Kammen 2001). 

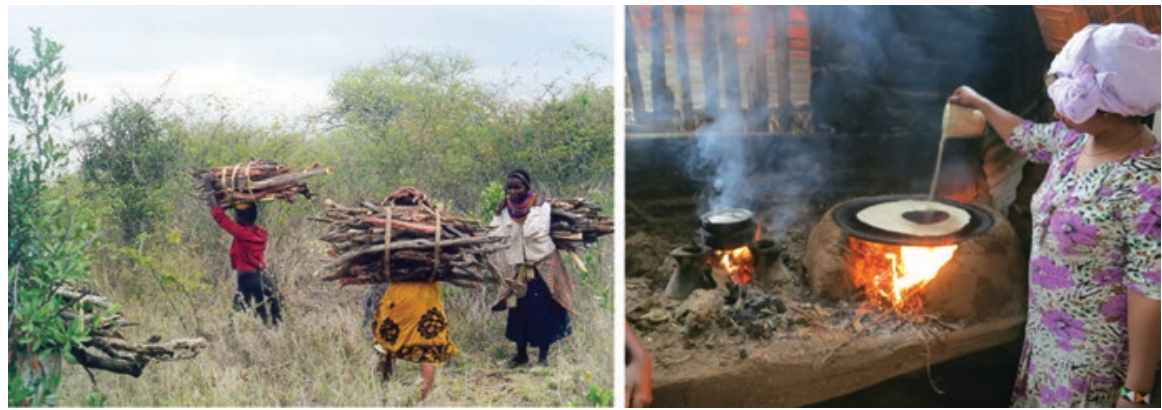

Fig. 26.2 Women collecting firewood in Kitui District, Kenya. Ethiopian injera stoves showing a common open access design with ease of use but also high energy loss. (Photo credits: Daniel M. Kammen)

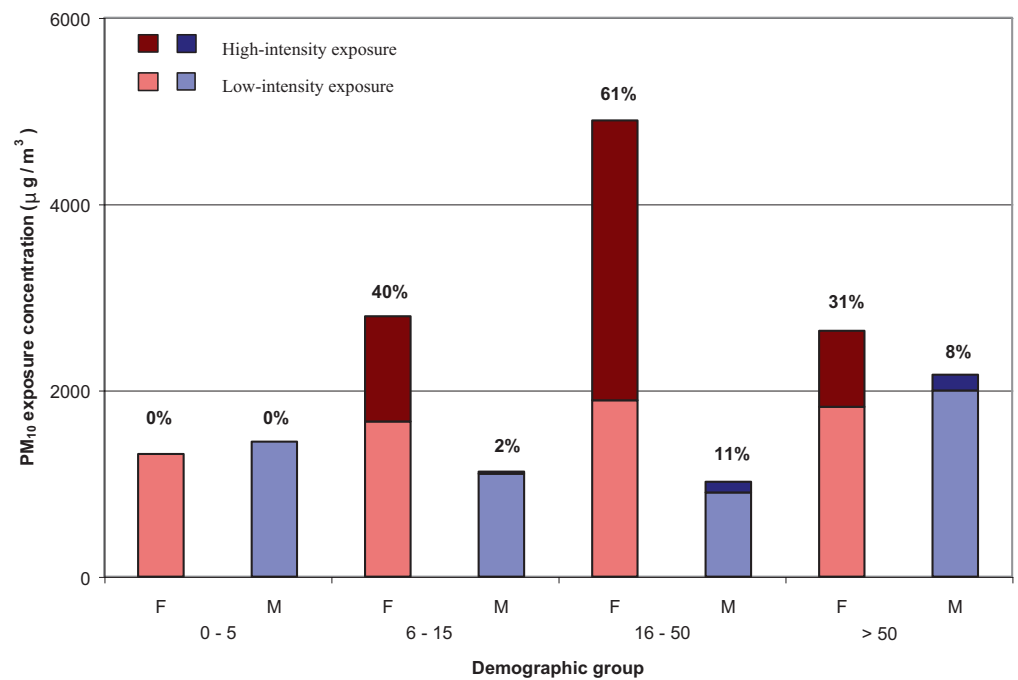

Fig. 26.3 Total daily exposure to particulate matter $10 \mu \mathrm{m}$ or less in diameter $\left(\mathrm{PM}_{10}\right)$, subdivided into high-intensity (darker shade) and low-intensity (lighter shade) exposure of each demographic

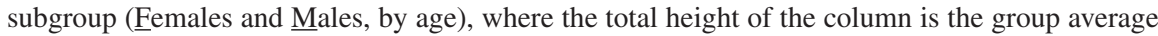
exposure concentration divided into the average for high- and low-intensity components. The percentages indicate the share of total exposure that is high-intensity exposure. The high-intensity component of exposure occurs in less than $1 \mathrm{~h}$, emphasizing the intensity of exposure in these episodes. For details, see Ezzati and Kammen (2001)

Figure 26.3 shows the exposure data obtained using an approach that considers the full exposure patterns and profile of individuals, divided into exposure during high-intensity and low-intensity episodes, respectively.

Increased access to clean energy sources can improve the day-to-day and longterm welfare of female household members. In fact, it has been argued that the increased prominence of biomass as an economic commodity (e.g., as a source 
of energy for small-scale manufacturing) has attracted local entrepreneurs and business actors-mostly men-driving women to assume more marginal social roles and depend on inferior sources of energy (Kammen, 1995). In our study, we found that the transition from traditional wood-burning stoves to the cleanest charcoal-burning stoves could cut pollution levels so significantly-largely for women and children - that there was literally no more cost-effective intervention (Ezzati \& Kammen, 2001) on a DALY (disability-adjusted life year) than childhood immunizations and improved cookstoves.

Cookstoves and cookstove programs have also been the subject of repeated criticisms that the stoves do not reduce pollution in practice in the field and thus the claimed benefits are illusory (see, for example, Gunther, 2015). As comes as no surprise to those who have studied not only stoves but the full life-cycle of maintenance, deployment, and education, stove/fuel/community partnerships that use the best stoves and focus on human economic and health benefits, and not just hardware, have proven successful (Goodman, 2018). Here again, we see a need to look beyond a technical fix and embrace the needed evolution from mundane science (Dove \& Kammen, 2015; Kammen \& Dove, 1997) to fulfil the full narrative of useinspired basic research—namely, that of Pasteur's quadrant.

\section{The Community Scale: Mini-grids}

The International Energy Agency (IEA) projects that over 900 million people in rural areas will remain without electricity by 2030, in contrast to only about 100 million in urban areas, with the vast majority being in sub-Saharan Africa (Alstone, Gershenson, \& Kammen, 2015). Sustainable Energy for All (SE4ALL, 2013), using data from the IEA, expects that achieving universal access will require grid extension for all new urban connections and $30 \%$ of rural populations, with the remaining $70 \%$ of rural people gaining access through decentralized solutions (via mini-grids, solar home systems (SHS), and intra-household (or "pico-") products, known widely as "pay-as-you-go" [PAYG] energy access technologies). In fact, a legitimate argument exists that despite "utility apologist" arguments, mini-grids will in time be cheaper, more reliable, and cleaner than large-grid systems (Casillas \& Kammen, 2010).

The economic limitations of the rural poor are reflected in their low energy consumption, struggle to pay connection fees, and challenges in procuring household wiring and appliances. In fact, many households and businesses in "electrified" areas lack access, even directly beneath power lines. People and communities without property rights may lack the stability to justify investments in fixed infrastructure, or may not have permission from central authority to do so. Figure 26.4 presents a representative mini-grid in Sabah, Malaysian Borneo, showing solar power (and micro-hydropower) powering telecommunications hardware and village lighting.

Figure 26.5 provides an overview of energy service provision from PAYG, minigrid, and large-grid systems. The battle for customers is one that distributed PAYG and mini-grid systems are increasingly winning —one home and $1 \mathrm{~kW}$ at a time. 


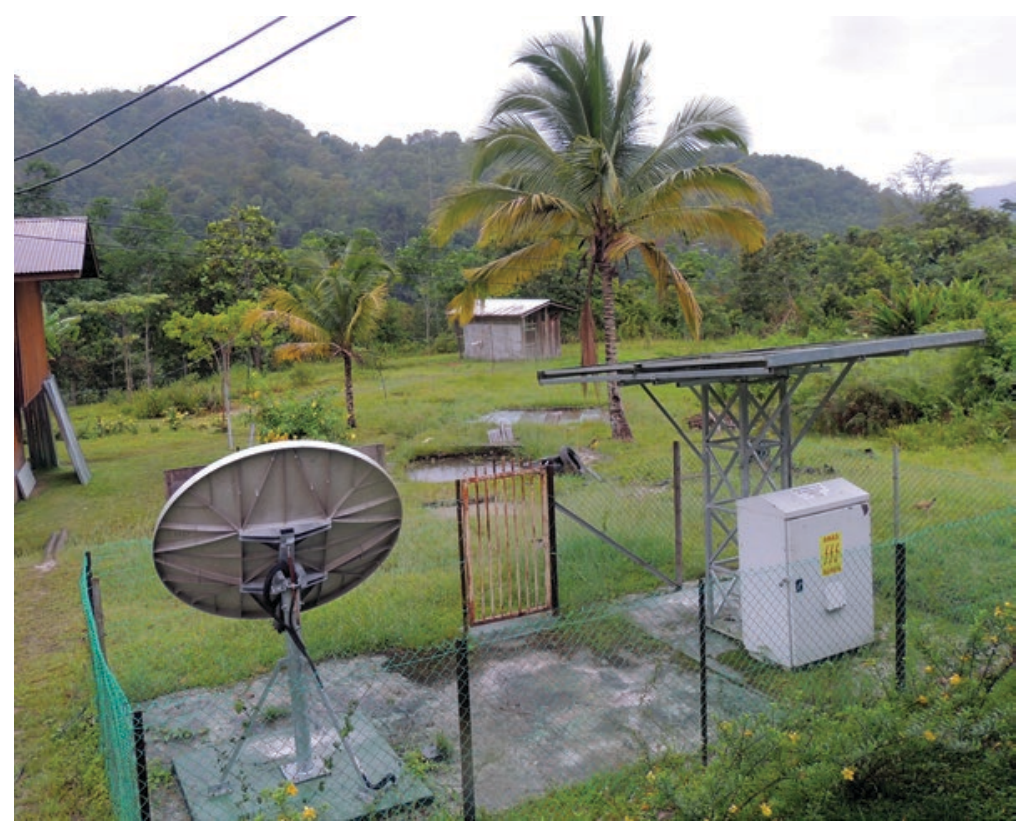

Fig. 26.4 A village micro-grid energy and telecommunications system in the Crocker Highlands of Sabah, Malaysian Borneo. The system serves a community of 200 and provides household energy services, telecommunications, and a satellite communications (dish shown), water pumping for fish ponds (seen in the center), and refrigeration. The supply includes micro-hydropower and solar generation (one small panel is shown here; others are distributed on building rooftops). (Photo credit: Daniel M. Kammen)

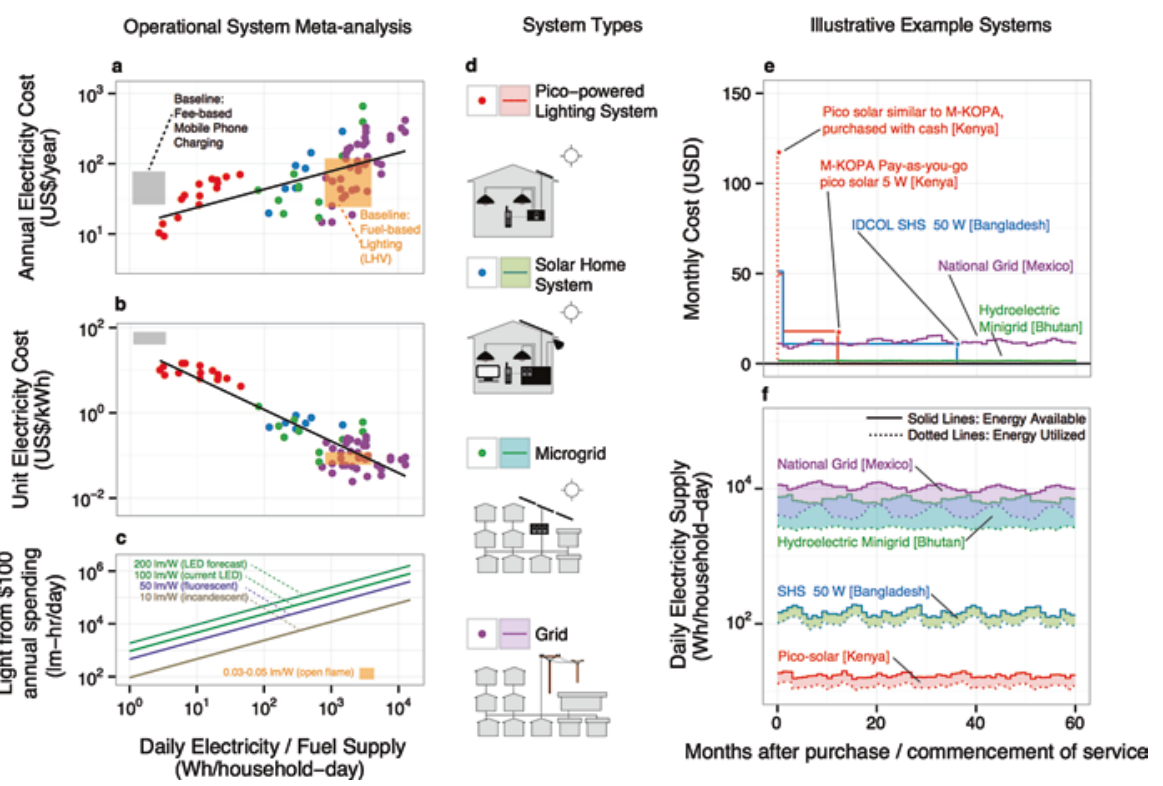

Fig. 26.5 Mapping of pay-as-you-go (PAYG), mini-grid, and large-scale grid technologies and levels of service provision (Alstone, Gershenson, and Kammen, 2015). IDCOL Infrastructure Development Company Limited, LED light-emitting diode, SHS solar home systems 


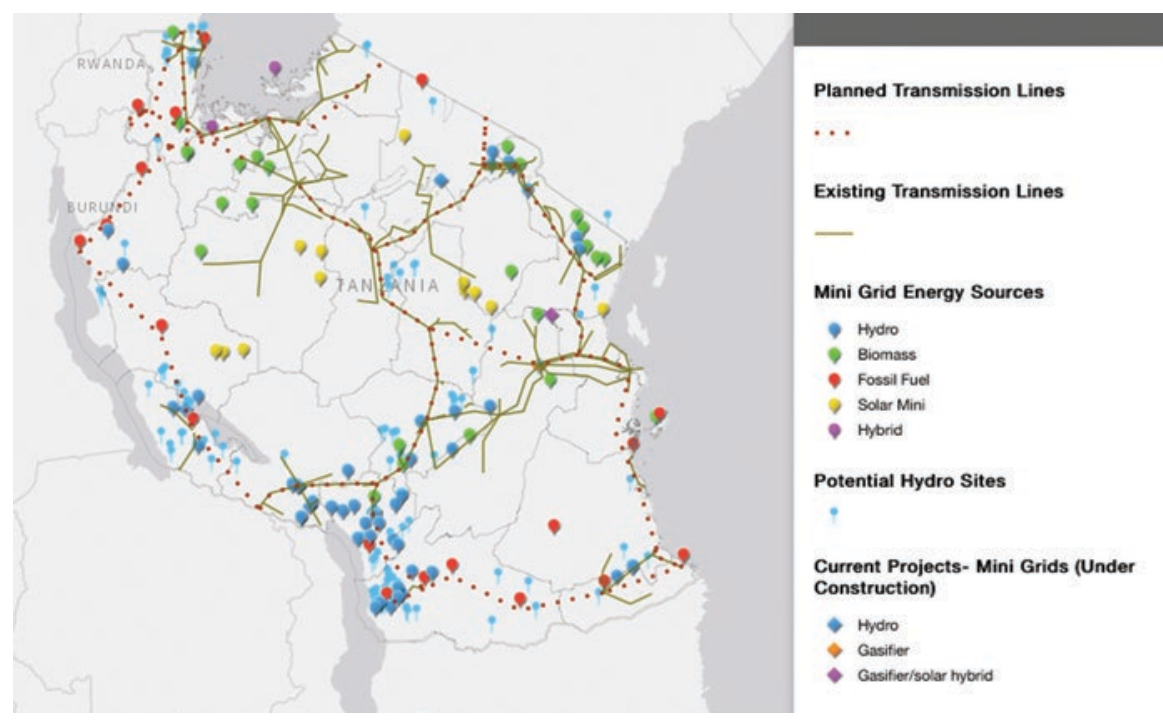

Fig. 26.6 Map of existing and planned utility grids and the proliferation of mini-grid systems across Tanzania. (Source: http://www.wri.org/resources/maps/tanzania-energy-access-maps). For additional mini-grid assessments, see Schnitzer et al., 2014. Similar maps are emerging worldwide

Globally, utility-scale grid expansion has roughly kept pace with the increase in the global population. In 2016, about 1.2 billion people were completely off-grid and many ostensibly connected people in the developing world experienced significant outages that ranged from 20 to 200+ days a year. Current forecasts are that this number will remain roughly unchanged until 2030, which would relegate a significant portion of the population and the economies of many of the neediest countries on earth to fragile, under productive lives, with fewer options than they could otherwise have (IPCC, 2011) (Fig. 26.6).

\section{Scientific Advances in Off-Grid Systems}

Mini-grids and products for individual user end-use, such as solar home systems, have benefited from dramatic price reductions and performance advances in solidstate electronics, cellular communications technologies, and electronic banking, and from the dramatic decrease in solar energy costs and more recently in storage costs (Kittner, Lil, \& Kammen, 2017). This mix of technological and market innovation has contributed to a vibrant new energy services sector, which in many nations has outpaced traditional grid expansion.

High-performance, low-cost photovoltaic generation paired with advanced batteries and controllers provide scalable systems across much larger power ranges 
than central generation, from megawatts down to fractions of a watt. As these minigrid and reliable utility-scale grid systems become more common and affordable, electrified cooking and thus very-low-pollution home environments become possible-further improving health outcomes.

\section{The Utility Scale: Grid Expansion and Its Dramatic Alternatives}

In 2008, I was approached by a consortium of nongovernmental organizations in Sabah, Malaysia, to offer alternatives to a coal-fired power plant. Sabah, a small and generally well-managed state, is the former British North Borneo, famous for rare megafauna and Mount Kinabalu. Our report Clean Energy Options for Sabah (McNish, Kammen, \& Gutierrez, 2010) (Fig. 26.7) and a great deal of community

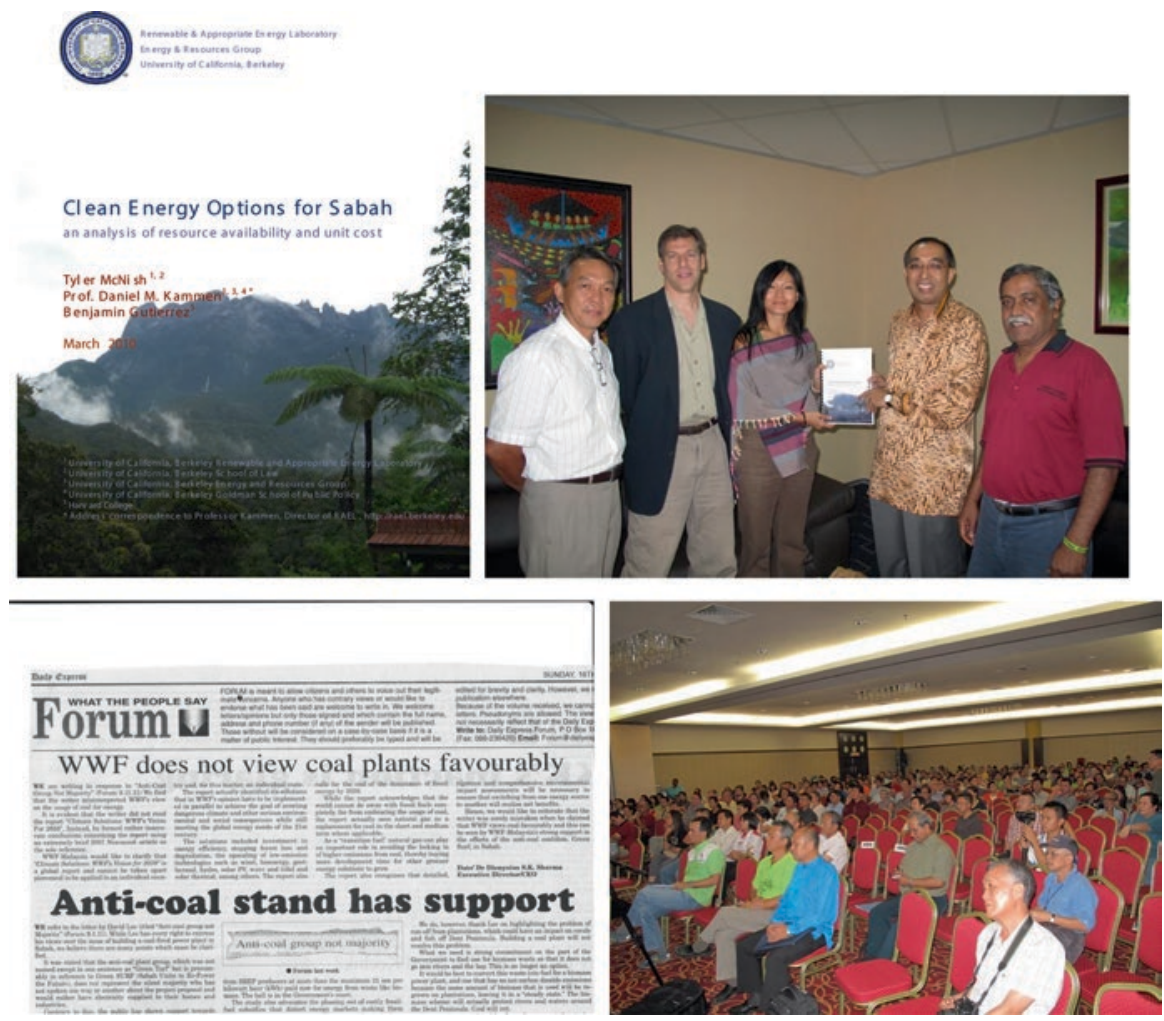

Fig. 26.7 Top left: The Renewable and Appropriate Technology Laboratory (RAEL) report, Clean Energy Options for Sabah. Top right: Presenting the Report to the environment minister. Bottom left: Coverage in The Borneo Post: "Anti-coal stand has support." Bottom right: Large public turnouts at events to discuss and debate the report's findings 
education and outreach helped to overturn a decision to purchase a 300-megawatt (MW) used coal-fired power plant from China in favor of investment in expanded distributed renewables, an improved grid, and natural gas. This victory helped to connect our team to a more challenging case, that of the larger and more ecologically and culturally brutalized state of Sarawak.

The victory against big coal in Sabah inspired a new kind of discussion around energy to happen across the region. Activists from throughout Asia working on campaigns against "dirty" energy projects like coal and dams were talking to clean and appropriate energy practitioners.

In 2002, as Sarawak was completing the Bakun Dam, one indigenous groupthe Kenyah-Badang community - that would have been displaced refused to accept the resettlement package and instead relocated their settlement just outside the dam's reservoir. Gara Jalong, the tenacious and charismatic leader of Long Lawen, had led the village against the many timber companies encroaching on indigenous lands in the 1980s, then against dam developers in the 1990s. Gara also sought out professionals with experience in rural electrification via micro-hydropower, to provide a sustainable source of energy for his people.

\section{A Clever Deception: The Sarawak Corridor of Renewable Energy}

Malaysian Borneo, like much of Southeast Asia, has experienced not only a brutal wave of deforestation but also a surge in mega-hydropower projects, ostensibly to facilitate industrial productivity and consumption. The Three Gorges Dam in China was completed in 2006, while the Nam Theun Dam (completed in 2010) and the Xayaburi Dam (under construction) in Laos were the first of a series of dams to be built in the trans-boundary Lower Mekong Basin. The island of Borneo, too, has abundant natural resources, immense global ecological importance, exotic megafauna (orangutans, dwarf rhino, and pygmy elephants) and hornbills, a largely rural human population (some of them former headhunters), and an agrarian economy, which is also on the cusp of major industrial dislocation due to hydropower development.

The Sarawak Corridor of Renewable Energy (SCORE) is a corridor in central Sarawak, an East Malaysian state on the island of Borneo. SCORE differs fundamentally from the other Malaysian economic corridor projects in its predominant emphasis on hydropower. At least 12 large hydroelectric dams and two coal power plants, together constituting $9380 \mathrm{MW}$ of capacity, were scheduled to be built before 2030 (Sovacool \& Bulan, 2012). Six dams were scheduled to be completed by 2020 , with three major dams already at different stages of development.

In 2012, the 2400 MW Bakun dam became operational. At 205 meters high, it is Asia's largest dam outside China. The dam's reservoir submerged $700 \mathrm{~km}^{2}$ of land and displaced about 10,000 people. In 2013, the 944 MW Murum Dam was completed and the 1200 MW Baram Dam was scheduled for construction. 
These projects-SCORE-summed to a targeted ninefold increase in energy output between 2010 and 2020, or from 5921 to $54,947 \mathrm{GWh}$, representing a $16 \%$ annual growth rate. In terms of installed capacity, this would translate into an expansion from $1300 \mathrm{MW}$ in 2010 to between 7000 and $8500 \mathrm{MW}$ in 2020. No extant demand existed for this power, yet the ecological and community damage would be extreme.

The story of SCORE was further complicated because with so many proposed dams but little quantitative analysis of the energy options or cost and benefit tradeoffs in the literature or the public discussion over this conflict, it was very hard for opposition to develop a clear narrative.

In response, we developed a modeling tool to examine the energy costs and land impacts of different energy choices. While that model is not described in technical detail here, the interested reader is directed to our papers that detail the analytic tool itself, the data sets, and many of the specific results (Shirley \& Kammen, 2015). Our results appeared locally in late 2015 , and we immediately began to hold open meetings to present these models and our findings (Fig. 26.8).

Our findings were stark and robust: Sarawak's already installed capacity including Bakun already exceeded expected demand in 2030 under the business-as-usual (BAU) growth assumption, so there was no additional need to build more capacity under the government's own BAU growth forecast. The Bakun Dam itself could provide more than $10,000 \mathrm{GWh}$ per annum. Under a $7 \%$ electricity demand growth assumption, this represented half of the expected demand in 2030. Even under the more aggressive $10 \%$ growth assumption, Bakun alone would satisfy a third of the demand in 2030. Completion of the two additional dams already under construction (Murum and Baram) would oversupply the 2030 demand under $7 \%$ growth, leading to a large excess capacity, and would require only a marginal amount of additional generation under $10 \%$ growth. Community energy-mini-grids-would preserve forests and provide local energy without household pollution.
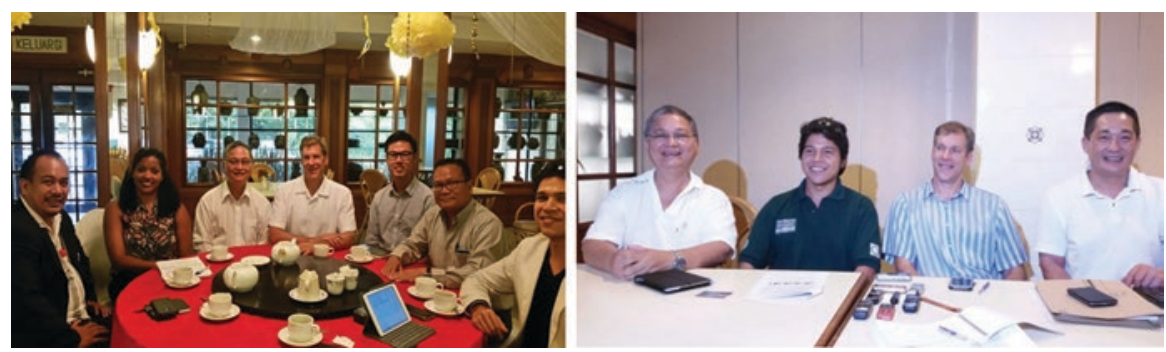

Fig. 26.8 Left: Activist team dinner with Dr. Rebekah Shirley (second from left) and Prof. Daniel Kammen (middle), flanked by community activist leaders from across Sabah and Sarawak. Right: Peter Kallang, the chairman of SAVE Rivers (far left), Gabriel Sundoro Wynn, the Asia regional director for Green Empowerment (second from left), Prof. Daniel Kammen (second from right), and See Hee Chow, a lawyer and Sarawak assemblyman (far right) 


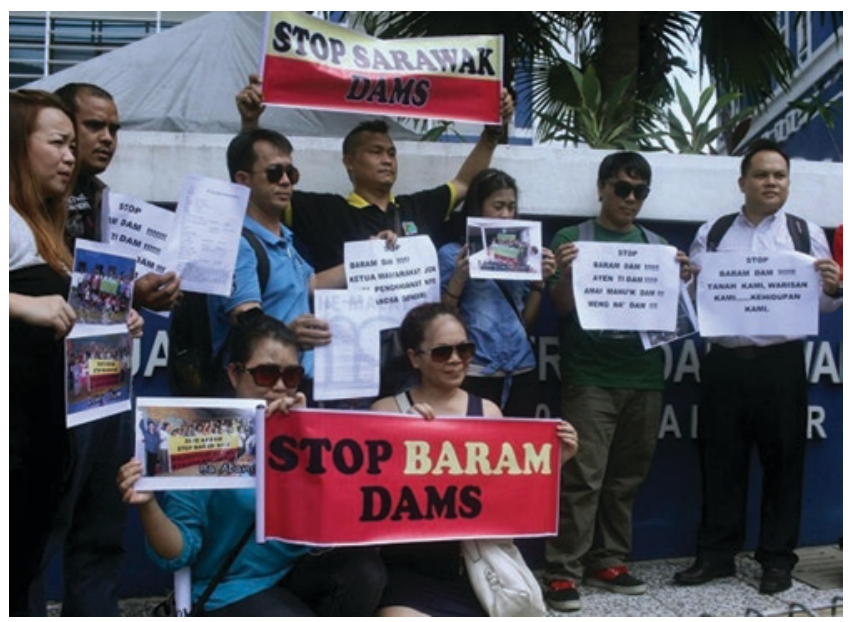

Fig. 26.9 Protesters citing (and holding) copies of the Shirley and Kammen study add ammunition to the wider social dialogue around the need for mega-dams and the dubious possibility of billions in foreign investment (from the article in The Borneo Post)

In response to the new study, press coverage (Fig. 26.9), indigenous protests, and a meeting I had with the chief minister, something remarkable and unexpected happened. On July 30, 2015, a moratorium on further work on the Baram Dam was announced by the chief minister.

Then, on March 21, 2016, a legal decision to solidify this position was announced: the Government of Sarawak revoked the classification of the land that the dam developers had used to extinguish the native rights of ownership of the contested dam site. This remarkable turnaround victory was a demonstration of local community activism and the importance of science communication, as research published by the Renewable and Appropriate Energy Laboratory, identifying financially viable commercial power production alternatives for the state, played a major role in the developments.

No environmental victory is ever final, of course. One moment's victory then demands constant vigilance, as anything can be overturned by a change in a political party, a shocking election result, or illegal land grabs and invasions. In the case of the Baram Dam, the paper was clear, but shortly thereafter the chief minister passed away. While the law stands, what was once final is never quite so final with the inevitable change of officials. For now, however, things are in a good place.

\section{Assessment: The Benefits of Diverse Technology Options to Provide Energy Services}

With these technological cornerstones at the household to community to large scales, aid organizations, governments, academia, and the private sector are developing and supporting a wide range of approaches to serve the needs of the poor, including pico- 
lighting devices (often very small 1- to 2-watt solar panels charging lithium ion batteries, which in turn power low-cost, high-efficiency light-emitting diode [LED] lights), solar home systems, and community-scale micro- and mini-grids. Decentralized systems are clearly not complete substitutes for a reliable grid connection, but they represent an important level of access until a reliable grid is available and feasible. They provide an important platform from which to develop more distributed energy services. By overcoming access barriers, often through marketbased structures, these systems provide entirely new ways to bring energy services to the poor and formerly unconnected people.

Meeting peoples' basic lighting and communication needs is an important first step on the "modern electricity service ladder" (Masera, Saatkamp, \& Kammen, 2000; Saatkamp, Masera, \& Kammen, 2000). Eliminating kerosene lighting from a household improves household health and safety while providing significantly higher quality and greater quantities of light. Fuel-based lighting is a $\$ 20$ billion industry in Africa, and tremendous opportunities exist to both reduce energy costs for the poor and improve the quality of service. Charging a rural or village cell phone can cost $\$ 5-10 / \mathrm{kWh}$ at a pay-for-service station but less than $\$ 0.50 / \mathrm{kWh}$ via an off-grid product or on a mini-grid.

This investment frees up income and also tends to lead to higher rates of utilization of cell phones and other small devices. Overall, the first few watts of power mediated through efficient end-uses lead to benefits in household health, education, and poverty reduction. Beyond basic needs, there can be a wide range of important and highly valued services from decentralized power (e.g., television, refrigeration, fans, heating, ventilation and air conditioning, and motor-driven applications), depending on the power level and its quality along with demand-side efficiency.

Testing laboratories that rate the quality of lighting products and disseminate the results are an invaluable step in increasing the quality and competitiveness of new entrants into the off-grid and mini-grid energy services space. The Lighting Global (https://www.lightingglobal.org) program is one example of an effort that began as an industry watchdog but has now become an important platform that provides market insights; steers quality assurance frameworks for modern, off-grid lighting devices and systems; and promotes sustainability through a partnership with industry.

As we explore the human and environmental impacts of pollution, it comes as no surprise that the range of costs only rises. In a recent study of the legacy of coal in Kosovo, the trace metals recorded in both the coal and coal dust that are deposited in the local area (which contains Pristina, the capital city, only $10 \mathrm{~km}$ from the mine and power plant) are at health-damaging levels, and have been for decades (Kittner, Fadadu, Buckley, Schwarzmann, \& Kammen, 2018). 


\section{An Action Agenda for Clean Energy for Human and Environmental Health and Energy Access}

\section{Exploit Information Technology}

The information technology revolution has dramatically closed the gap between off-grid, mini-grid, and utility-grid-scale management solutions and costs. In fact, the diversity of new energy service products available and the rapidly increasing demand for information and communication services, water, health, and entertainment in villages worldwide have built a very large demand for reliable and low-cost energy. Combining this demand with the drive for clean energy brings two important objectives, which were for many years seen as being in direct competition with alignment around the suite of new clean energy products that can power village energy services.

To enable and expand this process, a range of design principles that can form a roadmap to clean energy economies emerges:

Establish clear goals at the local level: Universal energy access is the global goal for 2030, but establishing more near-term goals that embody meaningful steps from the present situation will show what is possible and at what level of effort. Cities and villages have begun with audits of energy services, costs, and environmental impacts.

Empower villages as both designers and consumers of localized power: Village solutions necessarily vary greatly, but clean energy resource assessments, evaluation of the needs of the community, planning infrastructure, and training are all key to making the village energy system a success. In a pilot project in rural Nicaragua, once the assessment was complete, movement from evaluation to implementation quickly became a goal of both the community and a local commercial plant.

Make equity a central design consideration: Community energy solutions have the potential to liberate women entrepreneurs and disadvantaged ethnic minorities by tailoring user materials and energy plans to meet the cultural and linguistic needs of these communities. National programs often ignore business specialties, culturally appropriate cooking, and other home energy needs. Thinking explicitly about this is good business and also makes the solutions much more likely to be adopted.

Each of these steps warrants a further narrative, one that relies not only on science and technology but also centrally on the narrative. Laudato Si' is such a text: a compelling argument that blends science, technology, and economics in a larger integral ecology that is as respectful of culture as it is of community and social justice, but one that at the same time presents a vision of the positive nexus of science, technology, policy, and, above all, culture and community. 
Acknowledgements This research was conducted in partnership with Dr. Rebekah Shirley, Green Empowerment, and the community nongovernmental organization TONIBUNG. The Save Sarawak Rivers Network (SAVE Rivers) was the central coordinating group that brought together community leaders, researchers, and public officials, and ensured continued attention and efforts over the years of work, and blockades, of the dams. SAVE Rivers was the group that proposed that the study be carried out and then involved the Bruno Manser Fonds. This research was funded by the Bruno Manser Fonds, the Rainforest Foundation Norway, the Karsten Family Foundation, and the Zaffaroni Family. Gabriel Sundoro Wynn and Peter Kallang provided much-needed corrections, added details, and have been inspiring colleagues throughout this work.

\section{References}

Alstone, P., Gershenson, D., \& Kammen, D. M. (2015). Decentralized energy systems for clean electricity access. Nature Climate Change, 5, 305-314.

Bailis, R. R., Ezzati, M., \& Kammen, D. M. (2005). Mortality and greenhouse gas impacts of biomass and petroleum energy futures in Africa. Science, 308, 98-103.

Casillas, C., \& Kammen, D. (2010). The energy-poverty-climate nexus. Science, 330, 1182.

Dove, M., \& Kammen, D. (2015). Science, society and environment: Applying physics and anthropology to sustainability. Taylor and Francis: London.

Ezzati, M., \& Kammen, D. M. (2001). Indoor air pollution from biomass combustion and acute respiratory infections in Kenya: An exposure-response study. The Lancet, 358, 619-624.

Goodman, J. (2018). Toxic smoke is Africa's quiet killer. An entrepreneur says his fix can make a fortune, The New York Times, December 6.

Gunther, M. (2015). These cheap, clean stoves were supposed to save millions of lives. What happened?, The Washington Post, October 29.

Intergovernmental Panel on Climate Change (IPCC) (2011). Special report on renewable energy sources and climate change mitigation. Cambridge: Cambridge University Press.

Kammen, D. M., \& Lankford, W. F. (1990). Cooking in the sunshine. Nature, 348, 385-386.

Kammen, D. M. (1995). Cookstoves for the developing world. Scientific American, 273, 72-75.

Kammen, D. M., \& Dove, M. R. (1997). The virtues of Mundane science. Environment, 39, 10-15. $38-41$.

Kittner, N., Fadadu, R., Buckley, H. L., Schwarzmann, M., \& Kammen, D. M. (2018). Trace metal presence in lignite coal from Kosovo and associated air pollution-related risk. Environmental Science \& Technology, 52, 2359-2367.

Kittner, N., Lil, F., \& Kammen, D. M. (2017). Energy storage deployment and innovation: A multitechnology model for the clean energy transition. Nature Energy, 2, 17125.

Masera, O., Saatkamp, B., \& Kammen, D. M. (2000). From fuel switching to multiple cooking fuels: A critique of the energy ladder model in rural households. World Development, 28, 2083-2103.

McNish, T., Kammen, D. M., \& Gutierrez, B. (2010). Clean energy options for Sabah. Sabah, Malaysia: Sabah Unite to Re-power the Future \& World Wide Fund for Nature, WWF.

Saatkamp, B., Masera, O., \& Kammen, D. M. (2000). Energy and health transitions in development science and planning: Fuel use, stove technology, and morbidity in Jarácuaro, México. Energy for Sustainable Development, 4, 5-14.

Schnitzer, D., Lounsbury, D. S., Carvallo, J. P., Deshmukh, R., Apt, J., \& Kammen, D. M. (2014). Microgrids for rural electrification: A critical review of best practices based on seven case studies. New York, NY: United National Foundation. Retrieved on February 16, 2020 from http://energyaccess.org/wp-content/uploads/2015/07/MicrogridsReportFINAL_high.pdf

SE4ALL (2013). Global tracking framework. New York, NY: United Nations Sustainable Energy For All. 
Shirley, R., \& Kammen, D. M. (2015). Energy planning and development in Malaysian Borneo: Assessing the benefits of distributed technologies versus large scale energy mega-projects. Energy Strategy Reviews, 8, 15-29.

Sovacool, B., \& Bulan, L. C. (2012). Energy security and hydropower development in Malaysia: The drivers and challenges facing the Sarawak Corridor of Renewable Energy (SCORE). Renewable Energy, 40, 113-129.

Stokes, D. (1997). Pasteur's quadrant: Basic science and technological innovation. Washington, DC: Brookings Institution.

Sunter, D., Castellanos, S., \& Kammen, D. M. (2019). Disparities in rooftop photovoltaics deployment in the United States by race and ethnicity. Nature Sustainability, 2, 71-76.

Open Access This chapter is licensed under the terms of the Creative Commons Attribution 4.0 International License (http://creativecommons.org/licenses/by/4.0/), which permits use, sharing, adaptation, distribution and reproduction in any medium or format, as long as you give appropriate credit to the original author(s) and the source, provide a link to the Creative Commons license and indicate if changes were made.

The images or other third party material in this chapter are included in the chapter's Creative Commons license, unless indicated otherwise in a credit line to the material. If material is not included in the chapter's Creative Commons license and your intended use is not permitted by statutory regulation or exceeds the permitted use, you will need to obtain permission directly from the copyright holder.

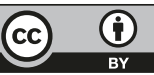

